\title{
Potentially toxic elements and persistent organic pollutants in water and fish at Shahid Rajaei Dam, north of Iran
}

\author{
A. Shakeri · R. Shakeri • B. Mehrabi
}

Received: 11 January 2014/Revised: 1 September 2014/Accepted: 5 January 2015/Published online: 22 January 2015

(C) Islamic Azad University (IAU) 2015

\begin{abstract}
The purpose of this study was to assess selected potentially toxic elements and persistent organic pollutants concentrations in the Shahid Rajaei Dam reservoir as well as their accumulation in barbel and Leuciscus cephalus fish species. The concentration of arsenic, mercury, nickel, chromium and cadmium in all water samples is less than WHO drinking water standard. Chromium shows a higher concentration than WHO standard in both fish species, while nickel and mercury content in barbel fish is higher than WHO standard. The result of principle component analyses indicates an increased elemental concentration due to application of phosphorus fertilizers in the agricultural lands, especially paddy field, ending up to the Tajan River and Shahid Rajaei Dam reservoir. Ni, Co, Mn, Pb and $\mathrm{Cr}$ display a quasi-independent behavior within the groups (PC1, PC2 and PC3) reflecting contribution of both geogenic and anthropogenic sources. The concentrations of persistent organic pollutants in all water samples, except M-5 sample, are less than WHO and EPA drinking water standards, while persistent organic pollutants (detected in both fish species) indicate higher contents than those of EPA standard values. Based on carcinogenic health risk value, maximum allowable fish consumption for arsenic is two meals per month. The result of noncarcinogenic health risk of mercury indicates one and three meals consumption per month for barbel and $L$. cephalus fishes, respectively. The calculation of maximum allowable fish consumption based on carcinogenic health for dieldrin, $\sum \mathrm{HCH}$,
\end{abstract}

A. Shakeri $(\bowtie) \cdot$ R. Shakeri · B. Mehrabi

Department of Geochemistry, Faculty of Earth Science,

Kharazmi University, 49 Mofatteh Avenue, P.O. Box 15614,

Tehran, Iran

e-mail: atashakeri@khu.ac.ir heptachlor epoxide, $\sum$ DDT and $\sum$ PCBs reveals monthly meals limitation of both fish species grown in Shahid Rajaei Dam.

Keywords Health risk assessment - Inorganic and organic pollutants - Maximum allowable fish consumption . Organochlorine pesticides · Polychlorinated biphenyls . Shahid Rajaei Dam

\section{Introduction}

The pollution of the aquatic environment with organic and inorganic pollutants has become a worldwide problem in recent years, as they are indestructible and most of them have toxic effects on organisms (Tanabe et al. 1994; MacFarlane and Burchett 2000; Malik et al. 2009; Dai et al. 2011). The major organic pollutants are polychlorinated biphenyls (PCBs) and organochlorine pesticides (OCPs), and inorganic one is potentially toxic elements (PTEs). These pollutants are ubiquitous contaminants in different environments (Martin et al. 2003; Fu and Wu 2005, 2006). Aquatic environments are important biotopes that should be controlled sensitively from unsafe industrial, agricultural and other anthropogenic activities (Mohiuddin et al. 2011; Zeng et al. 2013; Chakraborty and Owens 2014). PCBs are a group of chlorinated hydrocarbons widely used in industry with many different applications. However, their physical and chemical stability and also their lipophilic character make them serious environmental pollutants, which are highly persistent and tend to accumulate in soils, sediments, tissues and aquatic biota (Lana et al. 2008; Eqani et al. 2011). OCPs are organic compounds that to a varying degree resist photolytic, biological and chemical degradation. They are renowned for their persistence and 
bioaccumulation characteristics. Dieldrin and DDT, as well as the persistent organochlorine compounds of their decomposition, are still present in the environment, despite the ban on their use which was introduced in most countries in the 1970s (Cleemann et al. 2000; Feng et al. 2003; Eqani et al. 2011; Pawelczyk 2013). In fact, many of these compounds are now classified as the so-called persistent organic pollutants (POPs), because they can be recycled through food chains and produce a significant magnification of the original concentration at the end of the chain (Doong et al. 2002; Dai et al. 2011; Sharma et al. 2014). POPs are of international concern owing to their negative impact to both wildlife and human being due to lipophilic properties (Sanpera et al. 2002; Eqani et al. 2011). Agricultural lands cover a large part of the river basin and even in some areas in the world; these lands are located very close to the river. The use of PCBs and OCPs in the agricultural land has led to the accumulation of these compounds in the environment. Toxic elements enter in the environment from variety of sources (Dalai and Ishiga 2013). Main anthropogenic sources of heavy metal contamination are mining, disposal of domestic waste, as well as metal chelates from different industries and indiscriminate use of heavy metal-containing fertilizer and pesticides in agricultural fields (Nouri et al. 2008; Atar et al. 2012; Gupta et al. 2013). These pollutants migrate to surface and ground waters. They may also affect organisms directly by accumulating in their body or indirectly by transferring to the next species in food chain (Vander Oost et al. 2003; Sayg and Yigit 2012). Pollutant concentrations in aquatic ecosystems are usually monitored by measuring their concentrations in water, sediments and biota (Zhang et al. 2002; Dai et al. 2011; Eqani et al. 2011). Different groups of organisms can be used as a bioindicator of environmental change, though fish is usually considered as a good indicator of aquatic environmental changes and ecosystem health, especially in toxic pollution of waters (Yim et al. 2005; Moiseenko et al. 2008; Zrncic et al. 2013).

The Tajan River is one of the major rivers for water supply in north of Iran. The demand for water in the domestic, industrial and agricultural sectors of the Tajan River region is steadily increasing due to development, population growth as well as the demand for a sufficient food supply. For this purpose, Shahid Rajaei Dam was constructed on the Tajan River in 1997. This dam has been subjected to anthropogenic inputs of pollutants. Despite the potential for direct discharge of organic and inorganic contaminants into the Shahid Rajaei Dam reservoir, no measurement has been taken for monitoring the content and composition of POPs and trace metals in dam and Tajan River, especially in upstream. The Shahid Rajaei Dam receives discharges from agricultural land wastewater (approximately 1,800 ha, paddy field) and domestic and livestock wastewater. The present work is the first attempt for evaluating the PTEs and POPs contamination in the Shahid Rajaei Dam. Therefore, the concentrations of PTEs, OCPs and PCBs in water during two periods (November 2012 and September 2013) and fish in November 2012 were analyzed and compared. The main goals of present study are: (1) to determine the geochemical composition of the Shahid Rajaei Dam lake water, (2) to determine concentrations of persistent organic pollutants (OCPs and PCBs) and selected metals in water and their accumulation in fish, (3) to evaluate their hazard quotient (HQ), and (4) to calculate monthly fish consumption limits for carcinogenic and noncarcinogenic health of each contaminant.

\section{Materials and methods}

\section{Study area}

Shahid Rajaei Dam is located in $40 \mathrm{~km}$ south of the Sari City, in the northern part of Iran (Fig. 1) with 160 million cubic meters capacity and approximate catchment of $1,244 \mathrm{Km}^{2}$. It is constructed on the Tajan River, and its reservoir is fed by Shirinrood and Sefidrood rivers (in the confluence of these rivers, Tajan River arise). It was designed to provide irrigation, drinking and industrial water in the region. The main activities in this area are agriculture, crop irrigation and dairy activities. The main human settlements are in upstream including Ferim, Afrachal, Ali-Abad and Sekuya villages with a total of more than 10,000 habitants. Average temperature in the basin is $12{ }^{\circ} \mathrm{C}$, and average annual precipitation is about $650 \mathrm{~mm}$. Geological formations in the region in terms of lithology are mainly limestone, dolomitic limestone, sandstone, marl and shale (Fig. 1).

Sampling and analysis

For water quality assessment, nineteen samples were collected from the surface waters including nine sites along the Shirinrood (Sh-1 to Sh-9) and four sites along Sefidrood (S-1 to $\mathrm{S}-4)$ rivers in addition to five samples from Lake Dam (M-1 to M-5) and one sample from a mineral spring (Sp) during two periods (November 2012 and September 2013). Location of the sampling points is shown in Fig. 2. Each water sample was collected in a 1.5-1 polyethylene bottle. The bottles were thoroughly washed with dilute hydrochloric acid and then with distilled water in the laboratory. In field, each bottle was filled and emptied twice with the water to be sampled before sampling. Water samples were filtered using 0.45 - $\mu$ m-pore-size filter papers in order to separate particulate matter. The filtered samples 


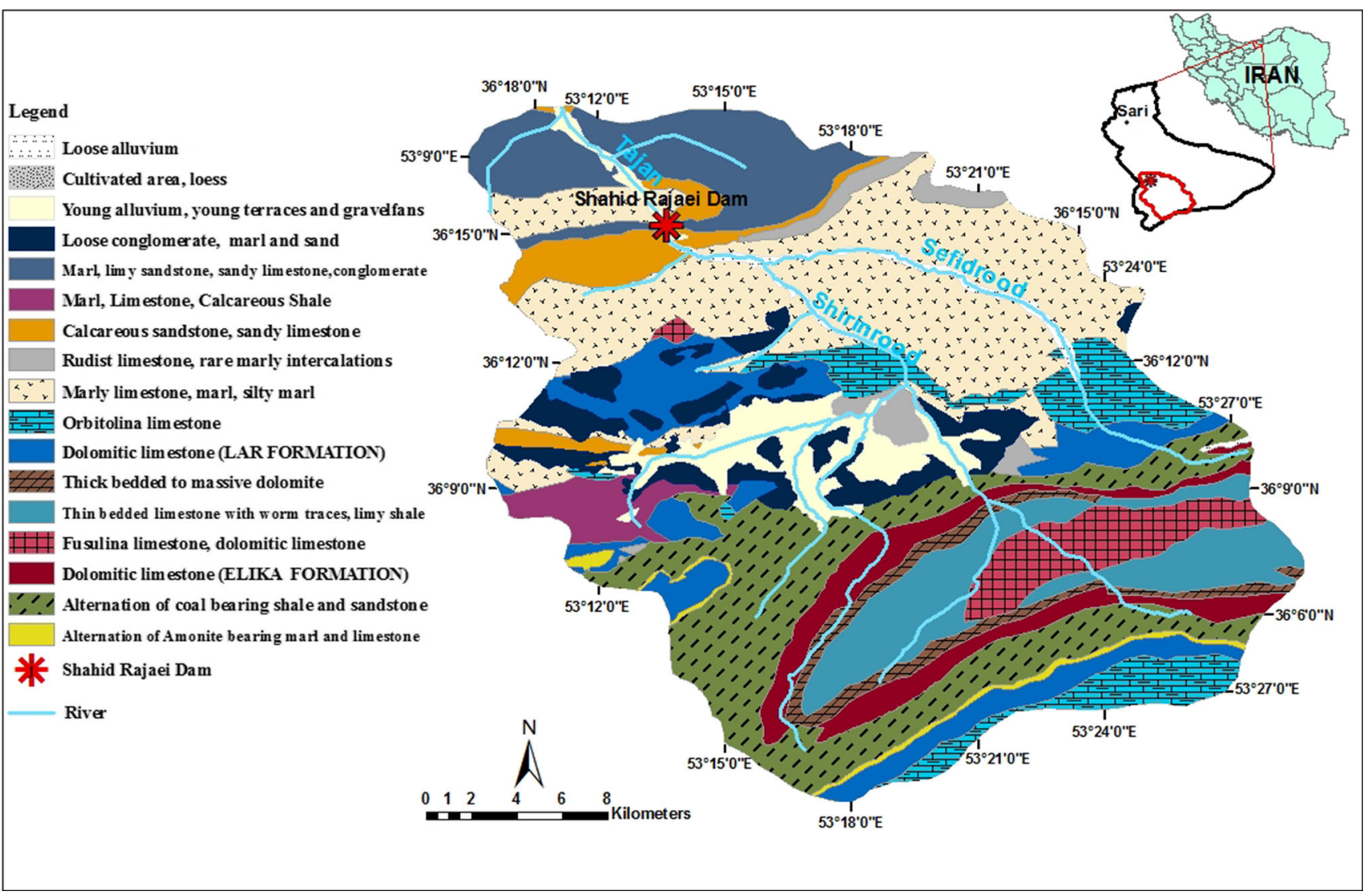

Fig. 1 Geological map of the study area

were then split into two subsamples: one was acidified with $\mathrm{HNO}_{3}$ for dissolved element measurement and the second one unacidified for the determination of dissolved anion. The samples were kept at $4{ }^{\circ} \mathrm{C}$ prior to analysis. Electrical conductivity (EC) and $\mathrm{pH}$ were measured in the field during sampling using portable measuring devices (Eutech instruments, PCD650). The concentrations of calcium, potassium, magnesium and sodium were measured using standard titration, and bicarbonate, sulfate and chloride ions were measured using ion chromatography techniques (in Mazandaran regional water laboratory). Trace elements and PTEs were analyzed by ICP-OES/ICP-MS in West lab, Australia. Certified reference materials, duplicates and reagent blanks were analyzed with each batch of samples for measuring accuracy, precision and baseline contamination, respectively. For measuring OCPs and PCBs, water samples at nine stations were collected in a 1-1 dark glass bottle and sent to the Kimia Shangarf Pars laboratory for gas chromatography (GC) analysis. Fish samples, including two species barbel and L. cephalus of Cyprinidae family, were collected from the Lake Dam. The fish samples were washed with deionized water, packed in polyethylene bags and kept at $-20{ }^{\circ} \mathrm{C}$, then transported on ice to the Kimia Shangarf Pars laboratory. In laboratory, $10 \mathrm{~g}$ of whole fish weight was prepared according to the EPA-821-08-021 (for PCBs) and EPA-821-R-00-017 (for OCPs) methods. POPs were analyzed by gas chromatography, and selected PTEs (As, $\mathrm{Cd}, \mathrm{Cr}, \mathrm{Ni}$ and $\mathrm{Hg}$ ) were analyzed by atomic absorption spectrometry.

\section{Statistical analysis}

Principal component analysis (PCA) is the most common multivariate statistical methods used in environmental studies (Kortatsi et al. 2009). It also helps in assigning source identity to each one of the PCs, as well as being a very powerful method of exploratory data processing and interpretation. PCA is widely used to reduce data (Loska and Wiechuya 2003) and to extract a small number of latent factors for analyzing relationships among the observed variables. The most common PCA type producing more interpretable components is the varimax rotation, which is applied in the current study. Factor loadings of $>0.71$ are typically regarded as excellent and $<0.32$ very poor for interpretation (Nowak 1998; Garcia et al. 2004). The number of significant principal components is selected on the basis of the Kaiser criterion with eigenvalue higher than 1 (Kaiser 1960). 


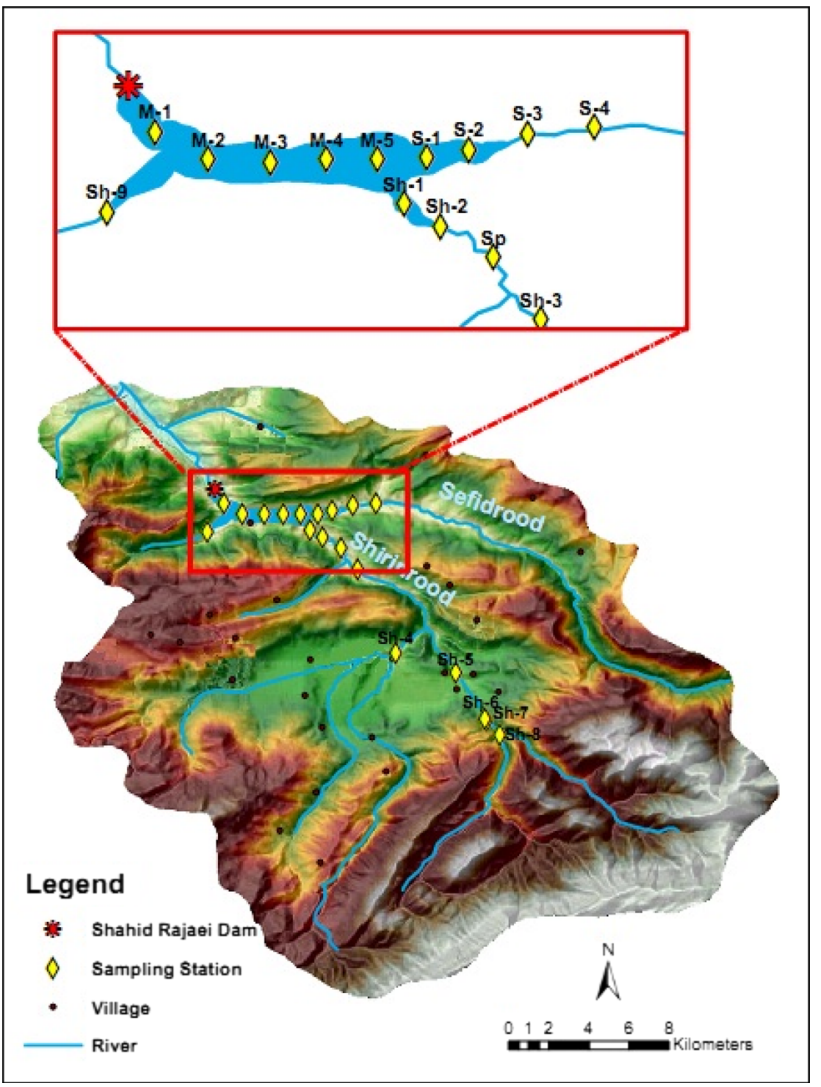

Fig. 2 Location of water sampling stations

\section{Risk assessment}

Hazard quotient (HQ)

To assess the public health risk of exposure to POPs and potentially toxic elements through fish consumption, the hazard quotient (HQ) is calculated by comparing the average daily doses (ADD) of a pollutant taken in, with the reference doses (RfD) (Vallero 2004; USEPA 1992). The HQ was calculated for each contaminant using Eq. (1).

$\mathrm{HQ}=\frac{\mathrm{ADD}}{\mathrm{R} f \mathrm{D}}$

The ADD exposure level (intake) is expressed in milligram per kilogram per day and is calculated by the Eq. (2).

$\mathrm{ADD}=\frac{C_{\mathrm{m}} \cdot \mathrm{CR}}{\mathrm{BW}}$

where: $\quad \mathrm{R} f \mathrm{D}=$ oral reference dose $\quad(\mathrm{mg} / \mathrm{kg} /$ day $)$; $\mathrm{ADD}=$ average daily dose $(\mathrm{mg} / \mathrm{kg} / \mathrm{day}) ; \mathrm{BW}=$ consumer body weight $(70 \mathrm{~kg}) ; C_{\mathrm{m}}=$ measured concentration of chemical contaminant $\mathrm{m}$ in fish $(\mathrm{mg} / \mathrm{kg}) ; \mathrm{CR}=$ mean daily fish consumption rate $(0.05 \mathrm{~kg} /$ day $)$
The HQ has been defined as if it is $<1.0$, there is no significant risk or systemic toxicity and ratios higher than 1.0 representing a potential risk. There is a likelihood that adverse outcome can occur at these concentrations, but an HQ $>1$ does not necessarily mean that adverse effects will occur (Vallero 2004).

Risk-based consumption limits

The USEPA approach is designed to manage health risks by providing risk-based consumption advice regarding contaminated fish (for example, one should limit consumption of a particular species to a specified number of meals per month or week). Two equations are used for deriving meals consumption limits for either carcinogenic or noncarcinogenic health effects. To calculate consumption limits for carcinogenic effects, it is necessary to specify an acceptable lifetime risk level (ARL). The appropriate risk level for a given population is determined by risk managers that calculate a risk level of 1 in 100,000 $\left(10^{-5}\right)$.

Equation (3) is used for calculating an allowable daily consumption of contaminated fish based on a contaminant's carcinogenicity, expressed in kilograms of fish consumed per day (USEPA 2000).

$\mathrm{CR}_{\lim }=\frac{\mathrm{ARL} \cdot \mathrm{BW}}{C_{\mathrm{m}} \cdot \mathrm{CSF}}$

Equation (4) is used for calculating an allowable daily consumption of contaminated fish, based on a contaminant's noncarcinogenic health effects and is expressed in kilograms of fish per day.

$\mathrm{CR}_{\lim }=\frac{\mathrm{R} f \mathrm{~d} \cdot \mathrm{BW}}{C_{\mathrm{m}}}$

where:

$\mathrm{CR}_{\text {lim }}=$ maximum allowable fish consumption rate $(\mathrm{kg} /$ day); $\mathrm{ARL}=$ maximum acceptable individual lifetime risk level (unit-less); $\mathrm{BW}=$ consumer body weight $(70 \mathrm{~kg})$; $C_{\mathrm{m}}=$ measured concentration of chemical contaminant $\mathrm{m}$ in fish $(\mathrm{mg} / \mathrm{kg}) ; \mathrm{CSF}=$ cancer slope factor $(\mathrm{mg} / \mathrm{kg} / \mathrm{day})$; $\mathrm{R} f \mathrm{D}=$ oral reference dose $(\mathrm{mg} / \mathrm{kg} /$ day $)$

Cancer slope factor and oral reference dose obtained from the USEPA Integrated Risk Information System for PTEs and POPs contaminants (http://www.epa.gov/iris/).

Equation (5) is used to convert daily consumption limits, in kilograms, to meals consumption limits over a given period (month) as a function of meals size (USEPA 2000).

$\mathrm{CR}_{\mathrm{mm}}=\frac{\mathrm{CR}_{\mathrm{lim}} \cdot T_{\mathrm{ap}}}{\mathrm{MS}}$

where: 
$\mathrm{CR}_{\mathrm{mm}}=$ maximum allowable fish consumption rate (meals/month); $T_{\mathrm{ap}}=$ time averaging period [365.25 day/ 12 months $=30.44 \quad$ (day/months) $; \quad$ MS $=$ meal size $(0.227 \mathrm{~kg}$ fish $/$ meals $)$

\section{Results and discussion}

\section{Major ion chemistry}

Major ions concentration, EC, TDS and $\mathrm{pH}$ of collected samples are summarized in Table 1 . The $\mathrm{pH}$ ranges from 7.4 to 8.1 with an average value of 7.9 in November 2012 and ranges from 7.1 to 8.1 with an average value of 7.8 in September 2013, which is reflecting the alkaline nature of the water samples. The EC and TDS values range from 307 to $1235 \mu \mathrm{s} / \mathrm{cm}$ and 304-945 mg/l with an average value of $462 \mu \mathrm{s} / \mathrm{cm}$ and $455 \mathrm{mg} / \mathrm{l}$, respectively. The order of cation chemistry for 16 water samples in November (Sh-1, Sh-2, Sh-3, Sh-5, Sh-6, Sh-7, Sh-8, S-1 to S-4, M-1 to M-5) is $\mathrm{Ca}^{++}>\mathrm{Mg}^{++}>\mathrm{Na}^{+}>\mathrm{K}^{+}$, while for Sh-4 and Sh-9 samples is $\mathrm{Ca}^{++}>\mathrm{Na}^{+}>\mathrm{Mg}^{++}>\mathrm{K}^{+}$and for the $\mathrm{Sp}$ mineral spring is $\mathrm{Na}^{+}>\mathrm{Ca}^{++}>\mathrm{Mg}^{++}>\mathrm{K}^{+}$. The order of cation chemistry for water samples, except Sh-1 $\left(\mathrm{Ca}^{++}>\mathrm{Na}^{+}>\mathrm{Mg}^{++}>\mathrm{K}^{+}\right)$and Sh-4 $\left(\mathrm{Ca}^{++}>\right.$ $\mathrm{Mg}^{++}>\mathrm{Na}^{+}>\mathrm{K}^{+}$), in September is similar to those of November. The sodium concentration ranges from 4.6 to $103.5 \mathrm{mg} / \mathrm{l}$ with an average of $16.3 \mathrm{mg} / \mathrm{l}$ in November and $4.6-142.6 \mathrm{mg} / \mathrm{l}$ with an average of $21.9 \mathrm{mg} / \mathrm{l}$ in September (Table 1). Sodium concentration for $\mathrm{Sp}$ mineral spring is higher than WHO and EPA standard values. Calcium and magnesium concentrations in water vary from 44 to 190 and 10.8 to $26.4 \mathrm{mg} / \mathrm{l}$ with average concentrations of 65 and $17.2 \mathrm{mg} / \mathrm{l}$, respectively. Potassium concentration varies between 1.56 and $4.29 \mathrm{mg} / \mathrm{l}$ with an average of $1.96 \mathrm{mg} / \mathrm{l}$ (Table 1). The order of anion concentration for all water samples except Sh-4, Sh-9 and Sp samples in November and $\mathrm{S}-1$ to $\mathrm{S}-4$ and $\mathrm{Sp}$ in September is $\mathrm{HCO}_{3}{ }^{-}>$ $\mathrm{SO}_{4}{ }^{-}>\mathrm{Cl}^{-}$. In general, bicarbonate and sulfate are the dominant anions ranging from 140.3 to $366.0 \mathrm{mg} / \mathrm{l}$ and 4.8 to $307.2 \mathrm{mg} / \mathrm{l}$ with average concentrations of 206.5 and $61.7 \mathrm{mg} / \mathrm{l}$, respectively. According to the Piper diagram, all water samples are $\mathrm{Ca}-\mathrm{HCO}_{3}-\mathrm{SO}_{4}$ type, while Sp mineral spring water is $\mathrm{Na}-\mathrm{HCO}_{3}-\mathrm{Cl}$ type (Fig. 3).

Phosphate concentration in unpolluted waters typically ranges from 0.01 to $0.1 \mathrm{mg} / \mathrm{l}$ (Samecka-Cymerman and Kempers 2001). The phosphate content for $89.5 \%$ of water samples is higher than this range (EPA standard $0.03 \mathrm{mg} / \mathrm{l}$ ). Phosphatic fertilizers used in agricultural lands in the Tajan basin may contribute to observe excess phosphate. In general, the mean concentration of $\mathrm{NO}_{3}{ }^{-}$and $\mathrm{NO}_{2}{ }^{-}$in the water samples is below the maximum allowable concentration (Table 1).
Inorganic and organic pollutants

Water

Concentration of selected trace elements and PTEs is summarized in Table 2. The average abundance order of trace elements contents for water samples in November is: $\mathrm{Fe}>\mathrm{Mn}>\mathrm{Zn}>\mathrm{Ni}>\mathrm{Cr}>\mathrm{Pb}>\mathrm{Mo}, \quad \mathrm{As}>\mathrm{Co}>\mathrm{Cd}$ and in September is: $\mathrm{Fe}>\mathrm{Mn}>\mathrm{Zn}>\mathrm{Cr}>\mathrm{Ni}>$ $\mathrm{Mo}>\mathrm{Pb}>\mathrm{Co}>$ As. The concentration of selected elements in water samples is as follows: $\mathrm{Fe}<10-290 \mu \mathrm{g} / \mathrm{l}, \mathrm{Mn}$

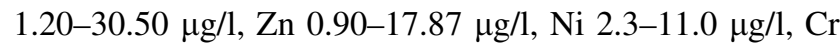
$1-6 \mu \mathrm{g} / \mathrm{l}, \mathrm{Pb} 0.4-4.4 \mu \mathrm{g} / \mathrm{l}$, Mo $0.30-1.89 \mu \mathrm{g} / \mathrm{l}$, As $<0.01-$ $1.60 \mu \mathrm{g} / \mathrm{l}$, Co $<0.02-0.63 \mu \mathrm{g} / \mathrm{l}$ and $\mathrm{Cd}<0.05-1.01 \mu \mathrm{g} / \mathrm{l}$. Concentrations of PTEs in all the water samples are less than WHO and EPA standard (Table 2).

The results of PCA for selected elements and major ions along with some physicochemical properties of water samples are presented in Table 3. Five factors are statistically representing the contributions influencing chemical composition of the water samples. These components describe $84.52 \%$ of the total variance of the data. The first component (PC1) explains $30.41 \%$ of the total variance, which is strongly and positively loading related to $\mathrm{Na}, \mathrm{Cl}$, $\mathrm{K}, \mathrm{NO}_{3}, \mathrm{Ca}, \mathrm{SO}_{4}$ and EC. $\mathrm{Ni}$ and $\mathrm{Co}$ display moderate positive loading, while $\mathrm{B}$ and $\mathrm{HCO}_{3}$ show weak positive loading. The presence of $\mathrm{Na}, \mathrm{Cl}, \mathrm{K}, \mathrm{Ca}, \mathrm{SO}_{4}$ and $\mathrm{NO}_{3}$ indicates the geogenic origin. PC2 explains $18.96 \%$ of the total variance and shows high positive loading on $\mathrm{HCO}_{3}$, $\mathrm{Mo}$ and $\mathrm{Cr}$, while $\mathrm{Ni}(0.59)$ and $\mathrm{Pb}(0.50)$ display moderate positive loading. High positive loading factor of bicarbonate in PC2 could be due to activity of plants root in aeration zone at the area with high rainfall in forest environment. Plant roots respire and produce $\mathrm{CO}_{2}$ which will turn to carbonic acid. High and moderate positive loadings of $\mathrm{HCO}_{3}$ with $\mathrm{Mo}, \mathrm{Cr}$, Ni and $\mathrm{Pb}$ reveal a significant role of bicarbonate ion in the dissolution and distribution of these elements in the surface water of the Tajan River and Shahid Rajaei Dam. PC3 has a high factor loading for $\mathrm{Fe}$ and $\mathrm{PO}_{4}$, and moderate positive loading for $\mathrm{Mn}(0.68), \mathrm{Co}(0.51), \mathrm{Cr}$ (0.59) and $\mathrm{pH}(0.54)$. As and $\mathrm{Ni}$ have weak positive loading. Nickel, $\mathrm{Co}, \mathrm{Mn}, \mathrm{Pb}$ and $\mathrm{Cr}$ display a quasi-independent behavior within the groups (PC1, PC2 and PC3) reflecting contribution of both geogenic and anthropogenic sources. The higher loadings of $\mathrm{PO}_{4}$ indicate amplified concentration due to application of phosphorus fertilizers as well as organophosphate pesticides in the agricultural lands, especially paddy field, ending up to the Tajan River and Shahid Rajaei Dam reservoir. High and moderate loadings of $\mathrm{Fe}$ and $\mathrm{pH}$ on $\mathrm{PC} 3$ indicate that iron content and $\mathrm{pH}$ play a significant role in dissolution and distribution of $\mathrm{Cr}, \mathrm{Ni}$ and $\mathrm{Co}$. $\mathrm{PC} 4$ has a high factor loading for $\mathrm{Cd}$, $\mathrm{Zn}$ and significant positive loading for $\mathrm{Pb}$, indicating a 
Table 1 Concentration of major ions (mg/l) along with some physicochemical properties of water

\begin{tabular}{|c|c|c|c|c|c|c|c|c|c|c|c|c|c|}
\hline Sample no. & $\mathrm{pH}$ & $\mathrm{EC}$ & TDS & $\mathrm{Ca}^{++}$ & $\mathrm{Mg}^{++}$ & $\mathrm{Na}^{+}$ & $\mathrm{K}^{+}$ & $\mathrm{HCO}_{3}{ }^{-}$ & $\mathrm{Cl}^{-}$ & $\mathrm{NO}_{3}^{-}$ & $\mathrm{NO}_{2}^{-}$ & $\mathrm{SO}_{4}^{-}$ & $\overline{\mathrm{PO}_{4}{ }^{-}}$ \\
\hline \multicolumn{14}{|c|}{ November 2012} \\
\hline S-1 & 8.1 & 500 & 315 & 58 & 18.0 & 11.5 & 1.56 & 152.5 & 17.75 & 3.1 & 0.013 & 86.4 & 0.14 \\
\hline S-2 & 8.1 & 500 & 315 & 58 & 18.0 & 11.5 & 1.56 & 152.5 & 17.75 & 3.1 & 0.018 & 86.4 & 0.14 \\
\hline S-3 & 8.1 & 541 & 341 & 70 & 16.8 & 9.2 & 1.95 & 140.3 & 17.75 & 0.9 & 0.036 & 115.2 & 0.19 \\
\hline S-4 & 8.1 & 505 & 318 & 56 & 19.2 & 11.5 & 1.56 & 164.7 & 17.75 & 3.5 & 0.069 & 76.8 & 0.10 \\
\hline M-1 & 7.8 & 514 & 324 & 62 & 16.8 & 11.5 & 1.95 & 152.5 & 17.75 & 1.8 & 0.019 & 91.2 & 0.05 \\
\hline M-2 & 7.7 & 514 & 324 & 64 & 14.4 & 13.8 & 1.95 & 195.2 & 24.85 & 3.1 & 0.041 & 48.0 & 0.05 \\
\hline M-3 & 7.9 & 513 & 323 & 62 & 16.8 & 11.5 & 1.95 & 152.5 & 17.75 & 2.6 & 0.046 & 91.2 & 0.03 \\
\hline M-4 & 7.9 & 517 & 326 & 66 & 15.6 & 13.8 & 1.95 & 158.6 & 24.85 & 2.6 & 0.044 & 76.8 & 0.09 \\
\hline M-5 & 8.0 & 508 & 320 & 60 & 16.8 & 11.5 & 1.56 & 158.6 & 17.75 & 2.6 & 0.042 & 81.6 & 0.06 \\
\hline Sh-1 & 8.0 & 515 & 324 & 62 & 16.8 & 11.5 & 1.95 & 158.6 & 17.75 & 3.1 & 0.029 & 86.4 & 0.13 \\
\hline Sh-2 & 7.8 & 747 & 471 & 110 & 15.6 & 11.5 & 2.73 & 201.3 & 21.30 & 4.8 & 0.007 & 158.4 & 0.13 \\
\hline Sh-3 & 8.0 & 518 & 326 & 64 & 15.6 & 11.5 & 1.95 & 164.7 & 21.30 & 2.6 & 0.045 & 76.8 & 0.02 \\
\hline Sh-4 & 7.8 & 1,235 & 778 & 190 & 16.8 & 27.6 & 4.29 & 262.3 & 49.70 & 4.9 & 0.001 & 307.2 & 0.05 \\
\hline Sh-5 & 7.9 & 492 & 310 & 66 & 15.6 & 4.6 & 1.56 & 201.3 & 10.65 & 2.2 & 0.003 & 52.8 & 0.15 \\
\hline Sh-6 & 8.0 & 484 & 305 & 66 & 14.4 & 4.6 & 1.56 & 213.5 & 10.65 & 1.8 & 0.001 & 38.4 & 0.07 \\
\hline Sh-7 & 7.9 & 485 & 306 & 66 & 14.4 & 4.6 & 1.56 & 213.5 & 10.65 & 2.2 & 0.001 & 38.4 & 0.11 \\
\hline Sh-8 & 7.8 & 482 & 304 & 64 & 15.6 & 4.6 & 1.56 & 213.5 & 7.10 & 1.8 & 0.002 & 43.2 & 0.15 \\
\hline Sh-9 & 7.9 & 502 & 316 & 62 & 10.8 & 20.7 & 1.56 & 231.8 & 28.40 & 2.2 & 0.004 & 9.6 & 0.08 \\
\hline $\mathrm{Sp}$ & 7.4 & 983 & 619 & 60 & 26.4 & 103.5 & 3.51 & 366.0 & 113.60 & 1.8 & 0.008 & 19.2 & 0.02 \\
\hline \multicolumn{14}{|c|}{ September 2013} \\
\hline S-1 & 7.8 & 316 & 501 & 54 & 19.2 & 13.8 & 1.56 & 237.9 & 24.85 & 2.6 & 0.0300 & 9.6 & 0.14 \\
\hline S-2 & 7.8 & 319 & 507 & 54 & 19.2 & 13.8 & 1.56 & 244.0 & 24.85 & 3.1 & 0.0278 & 4.8 & 0.11 \\
\hline S-3 & 7.8 & 322 & 511 & 54 & 20.4 & 13.8 & 1.95 & 244.0 & 24.85 & 2.6 & 0.0285 & 9.6 & 0.15 \\
\hline S-4 & 7.8 & 319 & 507 & 54 & 19.2 & 13.8 & 1.56 & 244.0 & 24.85 & 1.8 & 0.0285 & 4.8 & 0.13 \\
\hline M-1 & 7.9 & 313 & 497 & 54 & 16.8 & 16.1 & 1.56 & 183.0 & 28.40 & 3.1 & 0.0429 & 43.2 & 0.09 \\
\hline M-2 & 7.8 & 313 & 497 & 54 & 16.8 & 16.1 & 1.95 & 183.0 & 28.40 & 3.1 & 0.0451 & 43.2 & 0.04 \\
\hline M-3 & 7.8 & 313 & 497 & 54 & 16.8 & 16.1 & 1.95 & 183.0 & 28.40 & 1.8 & 0.0450 & 43.8 & 0.02 \\
\hline M-4 & 7.8 & 313 & 497 & 54 & 16.8 & 16.1 & 1.95 & 183 & 28.40 & 1.8 & 0.0453 & 44.5 & 0.07 \\
\hline M-5 & 7.8 & 315 & 500 & 54 & 16.8 & 16.1 & 1.95 & 183 & 28.40 & 1.8 & 0.0457 & 48.0 & 0.05 \\
\hline Sh-1 & 7.8 & 312 & 496 & 54 & 16.0 & 16.2 & 1.56 & 164.7 & 28.40 & 1.8 & 0.1248 & 57.6 & 0.07 \\
\hline Sh-2 & 7.8 & 317 & 503 & 54 & 18.0 & 16.2 & 1.56 & 179.9 & 24.85 & 2.2 & 0.0294 & 57.6 & 0.09 \\
\hline Sh-3 & 7.8 & 318 & 504 & 54 & 19.2 & 13.8 & 1.56 & 201.3 & 24.85 & 2.2 & 0.0291 & 57.6 & 0.03 \\
\hline Sh-4 & 7.1 & 309 & 490 & 56 & 21.6 & 4.6 & 1.56 & 262.3 & 10.65 & 2.2 & 0.0067 & 48.0 & 0.08 \\
\hline Sh-5 & 8.1 & 307 & 488 & 64 & 18.3 & 17.2 & 1.95 & 181.3 & 16.52 & 3.1 & 0.0079 & 41.7 & 0.12 \\
\hline Sh-6 & 8.0 & 316 & 501 & 54 & 18.7 & 16.9 & 1.95 & 185.2 & 15.31 & 2.6 & 0.0217 & 40.8 & 0.12 \\
\hline Sh-7 & 8.0 & 310 & 492 & 54 & 18.0 & 16.4 & 1.95 & 174.3 & 15.17 & 1.8 & 0.0183 & 42.5 & 0.09 \\
\hline Sh-8 & 7.5 & 559 & 887 & 126 & 19.2 & 18.4 & 3.12 & 353.8 & 28.40 & 3.5 & 0.0083 & 96.0 & 0.17 \\
\hline Sh-9 & 7.8 & 315 & 500 & 54 & 16.3 & 18.1 & 1.56 & 249.9 & 18.23 & 2.2 & 0.0092 & 56.7 & 0.13 \\
\hline $\mathrm{Sp}$ & 7.9 & 595 & 945 & 44 & 10.8 & 142.6 & 3.51 & 353.8 & 113.60 & 1.3 & 0.0240 & 9.6 & 0.02 \\
\hline Average & 7.9 & 462 & 455 & 65 & 17.2 & 19.1 & 1.96 & 206.5 & 26.38 & 2.5 & 0.0275 & 61.7 & 0.09 \\
\hline Maximum & 8.1 & 1,235 & 945 & 190 & 26.4 & 142.6 & 4.29 & 366.0 & 113.60 & 4.9 & 0.1248 & 307.2 & 0.19 \\
\hline Minimum & 7.1 & 307 & 304 & 44 & 10.8 & 4.6 & 1.56 & 140.3 & 7.10 & 0.9 & 0.0007 & 4.8 & 0.02 \\
\hline USEPA & $6.5-8.5$ & - & 500 & - & - & $30-60$ & - & - & 250 & 10 & 1 & 250 & 0.03 \\
\hline WHO & $6-8$ & - & 1,500 & 200 & 150 & 50 & 12 & - & 250 & 50 & 3 & 250 & - \\
\hline
\end{tabular}

common source. PC5 reveals high factor loading for As and $\mathrm{B}$.

Considering extent of agricultural land in the study area, for determining the concentration of OCPs and PCBs, batch of three samples from the Shirinrood River (Sh-1, Sh-2 and Sh-3), Sefidrood River (S-1, S-2 and S-4) and the
Lake Dam (M-1, M-3 and M-5) was collected and analyzed (in total nine samples). The OCPs and PCBs concentrations of the water samples are shown in Table 4. The total concentrations of OCPs in water is in range of $<\mathrm{LoD}$ (Limit of Detection) to $0.73 \mu \mathrm{g} / \mathrm{l}$. The highest concentration was observed at M-5 station. The highest 
concentration of organochlorine pesticides were: $0.09 \mu \mathrm{g} / \mathrm{l}$ (beta-HCH and gamma-chlordane), $0.17 \mu \mathrm{g} / \mathrm{l}$ (gamma$\mathrm{HCH}), 0.01 \mu \mathrm{g} / \mathrm{l}$ (endrin and heptachlor epoxide), $0.03 \mu \mathrm{g} / \mathrm{l}$ (endrin ketone and alpha-endosulfane), $0.05 \mu \mathrm{g} / \mathrm{l}$ (dieldrin), $0.04 \mu \mathrm{g} / \mathrm{l}$ (alpha-chlordane), $0.12 \mu \mathrm{g} / \mathrm{l}$ (beta-endosulfane), $0.07 \mu \mathrm{g} / \mathrm{l}$ (endosulfane) and $0.1 \mu \mathrm{g} / \mathrm{l}\left(4,4^{\prime}\right.$-DDE and 4,4'-DDD). Dieldrin concentration at M-5 sample $(0.05 \mu \mathrm{g} / \mathrm{l})$ is higher than WHO standard $(0.03 \mu \mathrm{g} / \mathrm{l})$. In other samples, the concentrations of OCPs are lower than WHO standard (2011). Total PCBs concentrations in water samples are in range of $<\mathrm{LoD}$ to $0.95 \mu \mathrm{g} / \mathrm{l}$. The highest concentration of PCBs was observed at M-5 sample $(0.95 \mu \mathrm{g} / \mathrm{l})$, which is higher than EPA standard for drinking water $(0.5 \mu \mathrm{g} / \mathrm{l})$.

\section{Fish}

Mean concentrations of $\mathrm{As}, \mathrm{Ni}, \mathrm{Cr}, \mathrm{Hg}$ and $\mathrm{Cd}$ in barbel and L. cephalus fish species are shown in Fig. 4. Cadmium $(0.018 \mathrm{mg} / \mathrm{kg})$ and As $(0.035 \mathrm{mg} / \mathrm{kg})$ show the lowest concentration, while $\mathrm{Ni}(1.44 \mathrm{mg} / \mathrm{kg})$ and $\mathrm{Cr}(0.91 \mathrm{mg} / \mathrm{kg})$ hold the highest mean concentrations in barbel and L. cephalus fish species, respectively. The average abundance order of toxic elements contents in barbel fish is $\mathrm{Ni}>\mathrm{Cr}>\mathrm{Hg}>\mathrm{As}>\mathrm{Cd}$, while in $L$. cephalus fish is $\mathrm{Cr}>\mathrm{Hg}>\mathrm{Ni}>\mathrm{Cd}>\mathrm{As}$ (Fig. 4). The order in barbel fish is similar to the water samples $(\mathrm{Ni}>\mathrm{Cr}>$ As $>\mathrm{Cd}>\mathrm{Hg}$ ), except for $\mathrm{Hg}$. Mercury concentrations were very low in the water samples (<limit of detection), but concentrations in the fish samples were relatively high, suggesting a particularly high bioaccumulation tendency compared with the other investigated trace elements. For human health protection, guidelines of PTEs presence in fish tissue have been set by different international organizations such as USEPA and WHO standards (Fig. 4). Concentration of analyzed selected PTEs in barbel and L. cephalus fish species in comparison with WHO standard (1989) contents is as follow: Cadmium indicates lower concentration than the WHO standard in two fish species. Nickel and mercury concentration in barbel fish is higher than the WHO standard. Chromium in barbel and L. cephalus fish species reveals higher concentrations than the WHO standards $(0.15 \mathrm{mg} / \mathrm{kg})$.

The concentrations of OCPs and PCBs in fish samples are summarized in Table 5. The highest concentrations of OCPs are $45 \mu \mathrm{g} / \mathrm{kg}$ (beta-HCH), $71 \mu \mathrm{g} / \mathrm{kg}$ (delta-HCH), $20 \mu \mathrm{g} / \mathrm{kg}$ (heptachlor), $10 \mu \mathrm{g} / \mathrm{kg}$ (heptachlor epoxide), $518 \mu \mathrm{g} / \mathrm{kg} \quad$ (dieldrin), $44 \mu \mathrm{g} / \mathrm{kg} \quad\left(4,4^{\prime}-\mathrm{DDE}\right), \quad 8 \mu \mathrm{g} / \mathrm{kg}$ $\left(4,4^{\prime}-\mathrm{DDD}\right), \quad 216 \mu \mathrm{g} / \mathrm{kg} \quad\left(4,4^{\prime}-\mathrm{DDT}\right) \quad$ and $\quad 17 \mu \mathrm{g} / \mathrm{kg}$ (methoxychlor).

Delta-HCH, heptachlor, heptachlor epoxide, 4,4'-DDE, 4,4'-DDD and 4,4'-DDT indicate higher concentrations than those of EPA standard values (de Vlaming 2008; Davis et al. 2010) in both barbel and L. cephalus fish species (Table 5). Barbel fish has higher concentration of beta-HCH and dieldrin, while $L$. cephalus has higher concentration of methoxychlor compared with EPA guideline, respectively. The highest concentrations of PCBs for barbel and L. cephalus species were 17 (PCB28) and 45 (PCB28) $\mu \mathrm{g} / \mathrm{kg}$, respectively (Table 5). PCB28,

Fig. 3 Piper diagram of the water samples

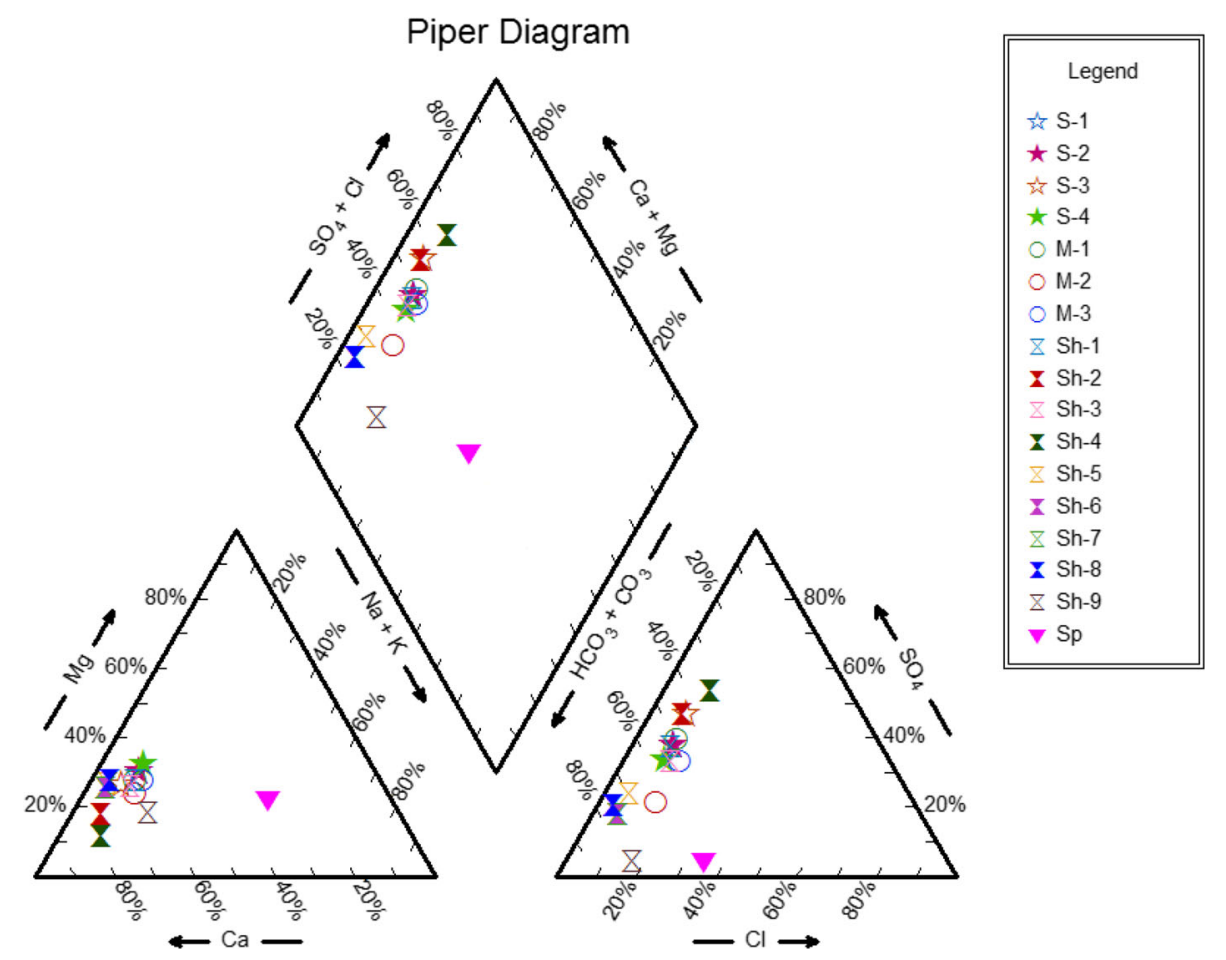


Table 2 Concentration of selected trace elements $(\mu \mathrm{g} / \mathrm{l})$ in water samples

\begin{tabular}{|c|c|c|c|c|c|c|c|c|c|c|c|}
\hline Sample no. & As & $\mathrm{Fe}$ & $\mathrm{Cr}$ & $\mathrm{Zn}$ & $\mathrm{Pb}$ & Mo & $\mathrm{Mn}$ & Co & $\mathrm{Cd}$ & $\mathrm{Hg}$ & $\mathrm{Ni}$ \\
\hline \multicolumn{12}{|l|}{ November 2012} \\
\hline S-1 & 0.01 & 60 & 4 & 4.08 & 3.2 & 1.48 & 6.81 & 0.20 & $<0.05$ & $<0.1$ & 3.6 \\
\hline S-2 & 0.02 & 65 & 2 & 2.47 & 0.8 & 1.29 & 4.65 & 0.19 & $<0.05$ & $<0.1$ & 3.7 \\
\hline S-3 & 0.03 & 80 & 1 & 1.68 & 0.9 & 1.23 & 28.10 & 0.16 & $<0.05$ & $<0.1$ & 4.1 \\
\hline S-4 & 0.02 & 70 & 3 & 3.93 & 2.5 & 1.15 & 9.30 & 0.20 & $<0.05$ & $<0.1$ & 4.5 \\
\hline M-1 & $<0.01$ & $<10$ & 1 & 1.20 & 0.4 & 1.62 & 4.90 & 0.20 & $<0.05$ & $<0.1$ & 2.3 \\
\hline M-2 & 0.02 & $<10$ & 2 & 1.42 & 0.5 & 1.41 & 9.70 & 0.21 & $<0.05$ & $<0.1$ & 3.7 \\
\hline M-3 & 0.04 & $<10$ & 1 & 1.62 & 0.7 & 1.55 & 1.20 & 0.25 & $<0.05$ & $<0.1$ & 3.2 \\
\hline M-4 & 0.03 & 15 & 1 & 1.58 & 0.8 & 1.48 & 4.40 & 0.22 & $<0.05$ & $<0.1$ & 2.6 \\
\hline M-5 & 0.03 & 60 & 2 & 1.50 & 0.5 & 1.56 & 3.70 & 0.24 & $<0.05$ & $<0.1$ & 2.8 \\
\hline Sh-1 & 0.05 & 60 & 3 & 17.87 & 3.6 & 1.55 & 4.80 & 0.21 & $<0.05$ & $<0.1$ & 3.9 \\
\hline Sh-2 & 0.04 & 50 & 2 & 3.06 & 3.4 & 1.47 & 16.90 & 0.19 & $<0.05$ & $<0.1$ & 5.4 \\
\hline Sh-3 & $<0.01$ & 45 & 1 & 1.48 & 0.5 & 1.47 & 4.50 & 0.20 & $<0.05$ & $<0.1$ & 2.8 \\
\hline Sh-4 & 0.03 & 90 & 2 & 2.37 & 1.4 & 1.89 & 18.20 & 0.22 & $<0.05$ & $<0.1$ & 8.7 \\
\hline Sh-5 & 0.03 & 80 & 1 & 1.34 & 0.7 & 1.32 & 8.40 & 0.17 & $<0.05$ & $<0.1$ & 3.9 \\
\hline Sh-6 & 0.02 & 65 & 1 & 1.75 & 1.1 & 1.45 & 3.40 & 0.19 & $<0.05$ & $<0.1$ & 4.1 \\
\hline Sh-7 & 0.03 & 70 & 1 & 1.23 & 0.8 & 1.53 & 4.10 & 0.21 & $<0.05$ & $<0.1$ & 4.3 \\
\hline Sh-8 & 0.02 & 70 & 3 & 2.39 & 1.4 & 1.85 & 2.30 & 0.38 & $<0.05$ & $<0.1$ & 4.1 \\
\hline Sh-9 & 0.01 & 85 & 2 & 2.04 & 1.0 & 1.12 & 6.45 & 0.25 & $<0.05$ & $<0.1$ & 5.9 \\
\hline $\mathrm{Sp}$ & 0.04 & 55 & 2 & 2.30 & 1.8 & 0.64 & 1.80 & 0.20 & $<0.05$ & $<0.1$ & 3.5 \\
\hline \multicolumn{12}{|l|}{ September 2013} \\
\hline S-1 & 1.20 & 60 & 2 & 2.10 & 0.7 & 0.80 & 8.81 & 0.51 & 0.15 & $<0.1$ & 4.2 \\
\hline S-2 & 1.20 & 80 & 1 & 1.50 & 0.5 & 0.80 & 6.65 & 0.58 & 0.14 & $<0.1$ & 3.8 \\
\hline S-3 & 1.10 & 290 & 4 & 8.70 & 2.6 & 0.50 & 30.50 & 0.52 & 0.31 & $<0.1$ & 5.6 \\
\hline S-4 & 1.20 & 140 & 3 & 14.50 & 3.0 & 0.80 & 11.30 & 0.53 & 0.22 & $<0.1$ & 5.9 \\
\hline M-1 & 0.90 & $<10$ & 1 & 1.50 & 0.5 & 0.80 & 6.93 & 0.20 & 0.14 & $<0.1$ & 3.3 \\
\hline M-2 & 1.00 & $<10$ & 1 & 10.30 & 1.5 & 0.80 & 11.70 & 0.16 & 0.76 & $<0.1$ & 4.2 \\
\hline M-3 & 0.80 & $<10$ & 1 & 1.00 & 0.4 & 0.80 & 2.96 & 0.35 & 0.13 & $<0.1$ & 3.4 \\
\hline M-4 & 1.00 & 30 & 1 & 17.50 & 3.6 & 0.70 & 6.40 & 0.10 & 1.01 & $<0.1$ & 3.6 \\
\hline M-5 & $<0.01$ & 80 & 1 & 6.90 & 1.1 & 0.70 & 5.72 & $<0.02$ & 0.14 & $<0.1$ & 3.8 \\
\hline Sh-1 & 1.20 & 80 & 1 & 1.70 & 0.9 & 0.80 & 6.86 & 0.37 & 0.26 & $<0.1$ & 4.0 \\
\hline Sh-2 & 0.60 & 100 & 2 & 9.80 & 2.0 & 1.10 & 20.40 & 0.46 & 0.23 & $<0.1$ & 6.5 \\
\hline Sh-3 & 0.50 & 60 & 1 & 1.70 & 0.7 & 0.90 & 6.72 & 0.23 & 0.09 & $<0.1$ & 3.6 \\
\hline Sh-4 & 0.50 & 290 & 3 & 6.40 & 3.1 & 1.40 & 22.50 & 0.63 & 0.31 & $<0.1$ & 11.0 \\
\hline Sh-5 & 0.50 & 190 & 4 & 4.60 & 3.4 & 1.20 & 10.60 & 0.09 & 0.15 & $<0.1$ & 5.2 \\
\hline Sh-6 & $<0.01$ & 140 & 4 & 8.80 & 2.0 & 1.30 & 5.84 & 0.61 & 0.16 & $<0.1$ & 5.4 \\
\hline Sh-7 & 0.70 & 140 & 5 & 8.40 & 2.6 & 1.40 & 6.09 & 0.27 & $<0.05$ & $<0.1$ & 5.9 \\
\hline Sh-8 & $<0.01$ & 120 & 2 & 8.90 & 4.4 & 1.40 & 4.14 & $<0.02$ & 0.12 & $<0.1$ & 5.3 \\
\hline Sh-9 & 1.60 & 220 & 6 & 4.60 & 2.6 & 1.00 & 8.88 & 0.33 & 0.23 & $<0.1$ & 7.1 \\
\hline $\mathrm{Sp}$ & $<0.01$ & 80 & 1 & 0.90 & 0.4 & 0.30 & 3.12 & 0.14 & 0.11 & $<0.1$ & 4.9 \\
\hline Average & 0.45 & 97.50 & 2.08 & 4.61 & 1.6 & 1.17 & 8.68 & 0.28 & 0.26 & $<0.1$ & 4.6 \\
\hline Maximum & 1.60 & 290 & 6 & 17.87 & 4.4 & 1.89 & 30.50 & 0.63 & 1.01 & $<0.1$ & 11.0 \\
\hline Minimum & $<0.01$ & $<10$ & 1 & 0.90 & 0.4 & 0.30 & 1.20 & $<0.02$ & $<0.05$ & $<0.1$ & 2.3 \\
\hline WHO (2011) & 10 & 300 & 50 & 300 & 10.0 & 70 & 500 & - & 3.00 & 1 & 20.0 \\
\hline USEPA (2012) & 10 & 300 & 100 & - & 15.0 & - & - & - & 5.00 & 2 & - \\
\hline
\end{tabular}


Table 3 Principal component analysis for variables in water samples

\begin{tabular}{|c|c|c|c|c|c|}
\hline \multirow[t]{2}{*}{ Component } & \multicolumn{5}{|c|}{ Rotated component matrix } \\
\hline & $\mathrm{PC} 1$ & $\mathrm{PC} 2$ & PC3 & $\mathrm{PC} 4$ & PC5 \\
\hline $\mathrm{EC}$ & 0.97 & 0.22 & 0.08 & 0.02 & -0.01 \\
\hline $\mathrm{K}$ & 0.97 & 0.13 & -0.01 & 0.07 & 0.01 \\
\hline $\mathrm{SO}_{4}$ & 0.97 & -0.10 & 0.14 & -0.06 & -0.11 \\
\hline $\mathrm{Ca}$ & 0.94 & 0.31 & 0.09 & 0.05 & -0.07 \\
\hline $\mathrm{Cl}$ & 0.83 & 0.07 & -0.04 & 0.14 & 0.50 \\
\hline $\mathrm{NO}_{3}$ & 0.78 & -0.06 & -0.20 & -0.03 & 0.07 \\
\hline $\mathrm{Na}$ & 0.72 & 0.04 & -0.07 & 0.06 & 0.64 \\
\hline $\mathrm{Ni}$ & 0.67 & 0.59 & 0.38 & 0.10 & 0.06 \\
\hline $\mathrm{HCO}_{3}$ & 0.38 & 0.89 & -0.03 & 0.13 & -0.01 \\
\hline Mo & 0.20 & 0.84 & -0.10 & -0.09 & -0.41 \\
\hline $\mathrm{NO}_{2}$ & -0.09 & -0.78 & -0.16 & 0.27 & 0.21 \\
\hline $\mathrm{Mg}$ & 0.27 & -0.76 & 0.15 & -0.19 & -0.41 \\
\hline $\mathrm{Cr}$ & -0.15 & 0.70 & 0.59 & 0.02 & 0.13 \\
\hline $\mathrm{Fe}$ & 0.17 & 0.22 & 0.86 & 0.05 & 0.03 \\
\hline $\mathrm{PO}_{4}$ & -0.24 & -0.02 & 0.76 & 0.09 & -0.30 \\
\hline $\mathrm{Mn}$ & 0.54 & -0.03 & 0.68 & 0.22 & 0.05 \\
\hline $\mathrm{pH}$ & -0.28 & -0.48 & 0.54 & -0.35 & 0.08 \\
\hline Co & 0.42 & -0.11 & 0.51 & -0.39 & 0.14 \\
\hline $\mathrm{Zn}$ & 0.03 & 0.02 & 0.12 & 0.88 & -0.12 \\
\hline $\mathrm{Cd}$ & 0.11 & -0.22 & -0.13 & 0.81 & 0.26 \\
\hline $\mathrm{Pb}$ & 0.04 & 0.50 & 0.30 & 0.68 & -0.24 \\
\hline As & -0.21 & -0.27 & 0.33 & 0.01 & 0.74 \\
\hline B & 0.29 & -0.01 & -0.29 & -0.14 & 0.72 \\
\hline$\%$ of variance & 30.41 & 18.96 & 14.23 & 10.48 & 10.45 \\
\hline Cumulative \% & 30.41 & 49.36 & 63.59 & 74.07 & 84.52 \\
\hline
\end{tabular}

Rotation method: varimax with Kaiser normalization
PCB37 (except L. cephalus2 and barbel1 samples), PCB44 (except L. cephalus2 and barbel2 samples), PCB138, PCB153 and PCB180 (except L. cephalus 1 sample) indicate higher concentrations than those of EPA standard values (de Vlaming 2008; Davis et al. 2010).

The result of hazard quotient for fish samples is presented in Table 6. The HQ for $\mathrm{As}, \mathrm{Cd}, \mathrm{Ni}$ and $\mathrm{Cr}$ except $\mathrm{Hg}$ in barbel and L. cephalus species is $<1.0$. The HQ value of dieldrin (OCP) in barbel fish and $\sum$ PCBs in both fish species were $>1.0$. HQ for other POPs in two fish species is below unit (Table 6).

The results of oral $\mathrm{R} f \mathrm{D}$ values, $\mathrm{CSF}$ values, allowable daily consumption and other values for $\mathrm{As}, \mathrm{Hg}, \mathrm{Cd}, \mathrm{Ni}, \mathrm{Cr}$ and POPs and their carcinogenic or noncarcinogenic health effects are summarized in Table 6. Based on $\mathrm{CR}_{\mathrm{mm}}$ value, maximum allowable barbel and $L$. cephalus fishes consumption for carcinogenic health of As is two meals per month (Approximately $0.5 \mathrm{~kg}$ ). The result of noncarcinogenic health for $\mathrm{Hg}$ indicates one and three meals consumption per month for barbel and L. cephalus fishes, respectively (Table 6). Maximum allowable barbel fish consumption for carcinogenic health is calculated as: $\sum \mathrm{HCH}$ (0.5 meals/month), heptachlor epoxide (1 meal/

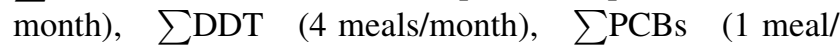
month). The calculated $\mathrm{CR}_{\mathrm{mm}}$ for dieldrin is indicating no consumption for barbel fish. Maximum allowable $L$. cephalus fish consumption for carcinogenic health is calculated as: $\sum \mathrm{HCH}$ ( 2 meals/month), heptachlor epoxide (1 meal/month), EDDT (1 meal/month). Monthly fish consumption limits for carcinogenic health $\sum$ PCBs in $L$. cephalus is 0.5 meals per month (Approximately $110 \mathrm{~g}$ ).

Table 4 Range of OCPs and PCBs concentration $(\mu \mathrm{g} / \mathrm{l})$ in the water samples

\begin{tabular}{llll}
\hline Compound & Concentration & Compound & Concentration \\
\hline Alpha-HCH & $<$ LoD & Gamma-Chlordane & $<$ LoD-0.09 \\
Beta-HCH & $<$ LoD-0.09 & Alpha-Chlordane & $<$ LoD-0.04 \\
Gamma-HCH & $<$ LoD-0.17 & Alpha-Endosulfane & $<$ LoD-0.03 \\
Delta-HCH & $<$ LoD & Beta-Endosulfane & $<$ LoD-0.12 \\
Aldrin & $<$ LoD & Endosulfane & $<$ LoD-0.07 \\
Dieldrin & $<$ LoD-0.05 & $4,4^{\prime}$-DDE & $<$ LoD-0.10 \\
Endrin & $<$ LoD-0.01 & $4,4^{\prime}$-DDD & $<$ LoD-0.10 \\
Endrin ketone & $<$ LoD-0.03 & $4,4^{\prime}$-DDT & $<$ LoD \\
Endrin aldehyde & $<$ LoD & Methoxychlor & $<$ LoD \\
Heptachlor & $<$ LoD & $\sum$ OCPs & $<$ LoD-0.73 \\
Heptachlor epoxide & $<$ LoD-0.01 & $\sum$ PCBs & $<$ LoD-0.95 \\
\hline
\end{tabular}

LoD: limit of detection $(<0.01 \mu \mathrm{g} / \mathrm{l})$

$\sum \mathrm{OCPs}=\mathrm{Sum}$ of (alpha- $\mathrm{HCH}$, beta-HCH, gamma-HCH, delta- $\mathrm{HCH}$, aldrin, dieldrin, endrin, endrin ketone, endrin aldehyde, heptachlor, heptachlor epoxide, gamma-chlordane, alpha-chlordane, endosulfane, alpha- endosulfane, beta-endosulfane, 4,4'-DDE, 4,4'-DDD, 4,4'-DDT and methoxychlor)

$\sum \mathrm{PCBs}=$ Sum of $32 \mathrm{PCB}$ congeners (IUPAC No. 8, 28, 37, 44, 49, 52, 60, 66, 70, 74, 77, 82, 87, 99, 101, 105, 114, 118, 126, 128, 138, 153, $156,158,166,169,170,179,180,183,187$ and 189) 


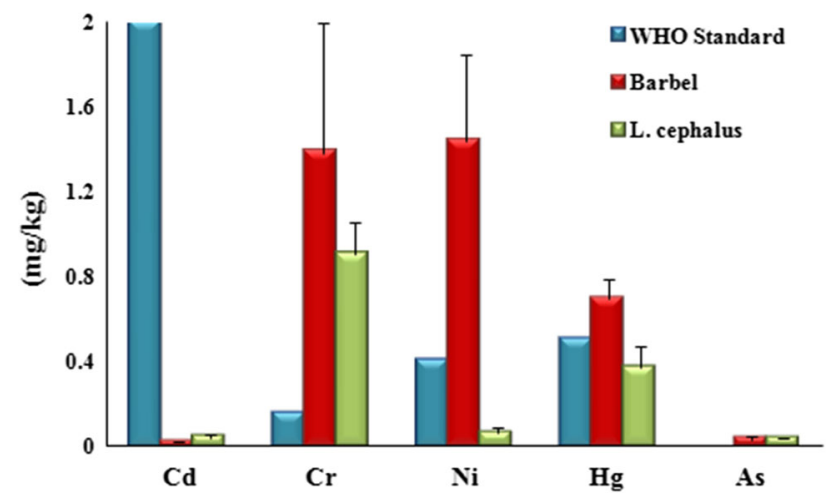

Fig. 4 Mean concentration levels of potentially toxic elements in barbel and L. cephalus fish and WHO standard

\section{Conclusion}

This article provides a basic data on inorganic and organic pollutants in water and their accumulation in two fish species from Shahid Rajaei Dam, North Iran. The results demonstrate that concentration of $\mathrm{As}, \mathrm{Cr}, \mathrm{Ni}, \mathrm{Co}$, $\mathrm{Mo}, \mathrm{Cd}, \mathrm{Cu}, \mathrm{Zn}, \mathrm{Pb}, \mathrm{Mn}, \mathrm{Fe}, \mathrm{Hg}$ and POPs (except dieldrin and $\sum$ PCBs contents for M-5 sample) in water are significantly lower than those of WHO drinking water standard. In contrast, $\mathrm{Cr}$ (in both fish), $\mathrm{Ni}$ and $\mathrm{Hg}$ (in barbel fish) and OCPs and PCBs (detected in the both fish species) indicate higher contents than WHO and EPA standard values, respectively, which suggests a particularly high bioaccumulation tendency in the fish samples.

Table 5 Organochlorine pesticides and polychlorinated biphenyls concentrations in the fish samples

\begin{tabular}{|c|c|c|c|c|c|}
\hline POPs $(\mu \mathrm{g} / \mathrm{kg})$ & Barbel-1 & Barbel-2 & Leuciscus cephalus-1 & Leuciscus cephalus-2 & EPA $(\mu \mathrm{g} / \mathrm{kg})$ \\
\hline \multicolumn{6}{|l|}{ OCPs } \\
\hline Alpha-HCH & ND & ND & ND & ND & 0.5 \\
\hline Beta-HCH & 45 & 40 & ND & ND & 1 \\
\hline Delta-HCH & 71 & 60 & 20 & 35 & 2 \\
\hline Gamma-HCH & ND & ND & ND & ND & 0.5 \\
\hline Heptachlor & 15 & 20 & 8 & 5 & 1 \\
\hline Heptachlor epoxide & 10 & 7 & 3 & 5 & 1 \\
\hline Aldrin & ND & ND & ND & ND & 1 \\
\hline Endrin & ND & ND & ND & ND & 2 \\
\hline Dieldrin & 480 & 518 & ND & ND & 0.5 \\
\hline $4,4^{\prime}-\mathrm{DDE}$ & 38 & 44 & 30 & 20 & 2 \\
\hline $4,4^{\prime}-\mathrm{DDD}$ & 8 & 5 & 6 & 4 & 1 \\
\hline $4,4^{\prime}-\mathrm{DDT}$ & 20 & 25 & 216 & 204 & 3 \\
\hline Alpha-endosulfane & ND & ND & ND & ND & 2 \\
\hline Beta-endosulfane & ND & ND & ND & ND & 5 \\
\hline Methoxychlor & ND & ND & 12 & 17 & 3 \\
\hline \multicolumn{6}{|l|}{ PCBs } \\
\hline PCB8 & ND & ND & ND & ND & 0.2 \\
\hline PCB28 & 17 & 15 & 45 & 40 & 0.2 \\
\hline PCB37 & ND & 5 & 10 & ND & 0.2 \\
\hline PCB44 & 4 & ND & 7 & ND & 0.2 \\
\hline PCB52 & ND & ND & ND & ND & 0.2 \\
\hline PCB87 & ND & ND & ND & ND & 0.2 \\
\hline PCB101 & ND & ND & ND & ND & 0.2 \\
\hline PCB118 & ND & ND & ND & ND & 0.2 \\
\hline PCB138 & 8 & 3 & 7 & 5 & 0.2 \\
\hline PCB153 & 6 & 3 & 8 & 2 & 0.2 \\
\hline PCB166 & ND & ND & ND & ND & 0.2 \\
\hline PCB179 & ND & ND & ND & ND & 0.2 \\
\hline PCB180 & 2 & 8 & ND & 6 & 0.2 \\
\hline
\end{tabular}


Table 6 Monthly fish consumption limits for carcinogenic and noncarcinogenic health endpoints and other parameters of inorganic and organic pollutants

\begin{tabular}{|c|c|c|c|c|c|c|c|c|c|c|c|}
\hline \multirow[t]{2}{*}{ Fish species } & \multicolumn{2}{|c|}{ Inorganic and organic pollutants } & \multirow[t]{2}{*}{$C_{\mathrm{m}}$} & \multirow[t]{2}{*}{ RfD } & \multirow[t]{2}{*}{ ADD } & \multirow[t]{2}{*}{ HQ } & \multirow[t]{2}{*}{ CSF } & \multicolumn{2}{|c|}{ Noncancer } & \multicolumn{2}{|l|}{ Cancer } \\
\hline & & & & & & & & $\mathrm{CR}_{\lim }$ & $\mathrm{CR}_{\mathrm{mm}}$ & $\mathrm{CR}_{\lim }$ & $\mathrm{CR}_{\mathrm{mm}}$ \\
\hline \multirow[t]{10}{*}{ Barbel } & \multirow[t]{5}{*}{ PTEs } & As & 0.0325 & 0.0003 & $2.3 \times 10^{-5}$ & 0.08 & 1.5 & 0.65 & 87 & 0.01 & 2 \\
\hline & & $\mathrm{Cd}$ & 0.018 & 0.001 & $1.3 \times 10^{-5}$ & 0.01 & NA & 3.89 & 521 & - & - \\
\hline & & $\mathrm{Hg}$ & 0.7 & 0.0001 & $5 \times 10^{-4}$ & 5.00 & NA & 0.01 & 1 & - & - \\
\hline & & $\mathrm{Ni}$ & 1.44 & 0.02 & $1.03 \times 10^{-3}$ & 0.05 & NA & 0.97 & 130 & - & - \\
\hline & & $\mathrm{Cr}$ & 1.39 & 0.02 & $9.9 \times 10^{-4}$ & 0.05 & NA & 1.01 & 135 & - & - \\
\hline & \multirow[t]{5}{*}{ POPs } & $\sum \mathrm{HCH}$ & 0.108 & $8 \times 10^{-4}$ & $8 \times 10^{-5}$ & 0.10 & 1.6 & 0.52 & 70 & 0.0041 & 0.5 \\
\hline & & Heptachlor epoxide & 0.009 & $1.3 \times 10^{-5}$ & $6 \times 10^{-6}$ & 0.47 & 9.1 & 0.11 & 14 & 0.0090 & 1 \\
\hline & & Dieldrin & 0.499 & $5 \times 10^{-5}$ & $3.6 \times 10^{-4}$ & 7.13 & 16 & 0.01 & 1 & 0.0001 & None \\
\hline & & $\sum \mathrm{DDT}$ & 0.070 & $5 \times 10^{-4}$ & $5 \times 10^{-5}$ & 0.10 & 0.34 & 0.50 & 67 & 0.0294 & 4 \\
\hline & & $\sum \mathrm{PCBs}$ & 0.036 & $2 \times 10^{-5}$ & $2.5 \times 10^{-5}$ & 1.27 & 2 & 0.04 & 5 & 0.0099 & 1 \\
\hline \multirow[t]{9}{*}{ Leuciscus cephalus } & \multirow[t]{5}{*}{ PTEs } & As & 0.035 & 0.0003 & $3 \times 10^{-5}$ & 0.08 & 1.5 & 0.60 & 80 & 0.01 & 2 \\
\hline & & $\mathrm{Cd}$ & 0.04 & 0.001 & $3 \times 10^{-5}$ & 0.03 & NA & 1.75 & 235 & - & - \\
\hline & & $\mathrm{Hg}$ & 0.37 & 0.0001 & $2.6 \times 10^{-4}$ & 2.64 & NA & 0.02 & 3 & - & - \\
\hline & & $\mathrm{Ni}$ & 0.065 & 0.02 & $4.6 \times 10^{-5}$ & 0.002 & NA & 21.54 & 2888 & - & - \\
\hline & & $\mathrm{Cr}$ & 0.91 & 0.02 & $6.5 \times 10^{-4}$ & 0.03 & NA & 1.54 & 206 & - & - \\
\hline & \multirow[t]{4}{*}{ POPs } & $\sum \mathrm{HCH}$ & 0.028 & $8 \times 10^{-4}$ & $2 \times 10^{-5}$ & 0.02 & 1.6 & 2.04 & 273 & 0.0159 & 2 \\
\hline & & Heptachlor epoxide & 0.004 & $1.3 \times 10^{-5}$ & $3 \times 10^{-6}$ & 0.22 & 16 & 0.23 & 31 & 0.0109 & 1 \\
\hline & & $\sum \mathrm{DDT}$ & 0.240 & $5 \times 10^{-4}$ & $1.7 \times 10^{-4}$ & 0.34 & 0.34 & 0.15 & 20 & 0.0086 & 1 \\
\hline & & $\sum \mathrm{PCBs}$ & 0.065 & $2 \times 10^{-5}$ & $4.6 \times 10^{-5}$ & 2.32 & 2 & 0.02 & 3 & 0.0054 & 0.5 \\
\hline
\end{tabular}

$C_{\mathrm{m}}=$ measured concentration of chemical contaminant $\mathrm{m}$ in a given species of fish $(\mathrm{mg} / \mathrm{kg}) ; \mathrm{R} f \mathrm{D}=$ oral reference dose $(\mathrm{mg} / \mathrm{kg} / \mathrm{day})$; $\mathrm{ADD}=$ average daily dose $\left(\mathrm{mg} / \mathrm{kg} /\right.$ day) $\mathrm{CR}_{\mathrm{lim}}=$ maximum allowable fish consumption rate $(\mathrm{kg} / \mathrm{day}) ; \mathrm{CR}_{\mathrm{mm}}=$ maximum allowable fish consumption rate (meals/month); CSF = cancer slope factor (mg/kg/day); NA = Not available in EPA's Integrated Risk Information System; None $=$ No consumption recommended

The results of maximum allowable fish consumption based on carcinogenic health for POPs, As and $\mathrm{Hg}$ reveal limitation for consumption of both fish species in Shahid Rajaei Dam. The possible sources of the OCPs and PCBs compounds and selected toxic elements are possibly the effluents from residential and agricultural areas. The levels of these pollutants may cause health impact on the aquatic environment and accompanied life. Since POPs and toxic elements levels in tissues of barbel and $L$. cephalus fish track the pollution gradient, these species appears to be useful for biomonitoring of POPs and metal accumulation, reflecting local pollution conditions and incorporating local bioavailability of these pollutants. Extended monitoring studies are necessary to fully understand the behavior and toxicological effects of organic and inorganic pollutants to the aquatic environments in north of Iran.

Acknowledgments The authors wish to express their gratitude to Kharazmi University for financial support (Grant No. 9911) and Mazandaran regional water company of Iran for logistic assistance.

\section{References}

Atar N, Olgun A, Wang S (2012) Adsorption of cadmium (II) and zinc (II) on boron enrichment process waste in aqueous solutions: batch and fixed-bed system studies. Chem Eng J 192:1-7

Chakraborty S, Owens G (2014) Metal distributions in seawater, sediment and marine benthic macroalgae from the South Australian coastline. Int J Environ Sci Technol 11:1259-1270

Cleemann M, Rigetm F, Paulsen GB, Klungsoyr J, Dietz R (2000) Organochlorines in Greenland marine fish, mussels, and sediments. Sci Total Environ 245:87-102

Dai GH, Liu XH, Liang G, Xu MZ, Han X, Shi L (2011) Health risk assessment of organochlorine contaminants in fish from a major lake (Baiyangdian lake) in North China. Bull Environ Contam Toxicol 87:58-64

Dalai B, Ishiga H (2013) Geochemical evaluation of present-day Tuul River sediments, Ulaanbaatar basin, Mongolia. Environ Monit Assess 185:2869-2881

Davis JA, Melwani AR, Bezalel SN, Hunt JA, Ichikawa G, Bonnema A, Heim WA, Crane D, Swenson S, Lamerdin C, Stephenson M (2010) Contaminants in fish from California Lakes and reservoirs, 2007-2008: summary report on a two-year screening survey. A Report of the Surface Water Ambient Monitoring Program (SWAMP). California State Water Resources Control 
Board, Sacramento. http://www.swrcb.ca.gov/water_issues/ programs/swamp/lakes_study.shtml

de Vlaming V (2008) Organochlorine pesticides and polychlorinated biphenyls (PCB) Concentrations in Muscle Tissue of Fish Collected from the San Joaquin River and Sacramento River Watersheds and Delta During 2005. Report prepared for: central valley regional water quality control board. http://www.swrcb. ca.gov/rwqcb5/water_issues/swamp/water_quality_reports/ devlaming_rpt.pdf

Doong RA, Sun YC, Liao PL, Peng CK, Wu SC (2002) The distribution and fate of organochlorine pesticides residues in sediments from the selected rivers in Taiwan. Chemosphere 48:237-246

Eqani SA, Malik RN, Mohammad A (2011) The level and distribution of selected organochlorine pesticides in sediments from River Chenab, Pakistan. Environ Geochem Health 33(1):33-47

Feng K, Yu BY, Ge DM, Wong MH, Wang XC, Cao ZH (2003) Organo-chlorine pesticide (DDT and $\mathrm{HCH}$ ) residues in the Taihu Lake Region and its movement in soil-water system. I. Field survey of DDT and $\mathrm{HCH}$ residues in ecosystem of the region. Chemosphere 50:683-687

Fu CT, Wu SC (2005) Bioaccumulation of polychlorinated biphenyls in mullet fish in a former ship dismantling harbor: a PCBcontaminated estuary and nestled coastal fish farms. Mar Pollut Bull 51:932-939

Fu CT, Wu SC (2006) Seasonal variation of the distribution of PCBs in sediments and biota in a PCB-contaminated estuary. Chemosphere 62:1786-1794

Garcia JH, Li WW, Arimoto R, Okrasinski R, Greenlee J, Walton J (2004) Characterization and implication of potential fugitive dust sources in the Paso del Norte region. Sci Total Environ 325:95-112

Gupta VK, Yola ML, Atar N, Ustundag Z, Solak AO (2013) A novel sensitive $\mathrm{Cu}$ (II) and $\mathrm{Cd}(\mathrm{II})$ nanosensor platform: graphene oxide terminated $p$-aminophenyl modified glassy carbon surface. Electrochim Acta 112:541-548

Kaiser HF (1960) The application of electronic computers to factor analysis. Educ Psychol Measur 20:141-151

Kortatsi BK, Anku YSA, Anornu GK (2009) Characterization and appraisal of facets influencing geochemistry of groundwater in the Kulpawn sub-basin of the White Volta Basin, Ghana. Environ Geol 58:1349-1359

Lana R, Vavrova M, Caslavsky J, Skoumalova M, Bilkova A, Sucman E (2008) Bull Environ Contam Toxicol 81:574-577

Loska K, Wiechuya D (2003) Application of principle component analysis for the estimation of source of heavy metal contamination in surface sediments from the Rybnik Reservoir. Chemosphere 51:723-733

Macfarlane GB, Burchett MD (2000) Cellular distribution of $\mathrm{Cu}, \mathrm{Pb}$ and $\mathrm{Zn}$ in the grey mangroove Avicennia marina (Forsk) Vierh. Aquat Bot 68:45-49

Malik A, Ojha P, Singh KP (2009) Levels and distribution of persistent organochlorine pesticide residues in water and sediments of Gomti river (India)-a tributary of the Ganges river. Environ Monit Assess 148:421-435

Martin M, Richardson BJ, Lam PKS (2003) Harmonisation of polychlorinated biphenyl (PCB) analyses for ecotoxicological interpretations of Southeast Asian environmental media: what's the problem? Mar Pollut Bull 46:159-170

Mohiuddin KM, Ogawa Y, Zakir HM, Otomo K, Shikazono N (2011) Heavy metals contamination in water and sediments of an urban river in a developing country. Int J Environ Sci Technol 8:723-736

Moiseenko TI, Gashkina NA, Sharova YN, Kudriavtseva LP (2008) Ecotoxicological assessment of water quality and ecosystem health: a case study of the Volga River. Ecotoxicol Environ Saf $71: 837-850$
Nouri J, Mahvi AH, Jahed GR, Babaei AA (2008) Regional distribution pattern of groundwater heavy metals resulting from agricultural activities. Environ Geol 55:1337-1343

Nowak B (1998) Contents and relationship of elements in human hair for a non-industrialized population in Poland. Sci Total Environ 209:59-68

Pawelczyk A (2013) Assessment of health risk associated with persistent organic pollutants in water. Environ Monit Assess 136:155-165

Samecka-Cymerman A, Kempers AJ (2001) Concentrations of heavy metals and plant nutrients in water, sediments, and aquatic macrophytes of anthropogenic lakes (former open cut brown coal mines) differing in stage of acidification. Sci Total Environ 281:87-98

Sanpera C, Ruiz X, Llorente GA, Jover L, Jabeen R (2002) Persistent organochlorine compounds in sediment and biota from the Haleji lake: a wild life sanctuary in south Pakistan. Bull Environ Contam Toxicol 68:237-244

Sayg Y, Yigit SA (2012) Assessment of metal concentrations in two cyprinid fish species (L. cephalus and Tinca tinca) captured from Yenic, aga Lake, Turkey. Bull Environ Contam Toxicol 89:86-90

Sharma BM, Bharat GK, Tayal S, Nizzetto L, Cupr P, Larssen T (2014) Environment and human exposure to persistent organic pollutants (POPs) in India: a systematic review of recent and historical data. Environ Int 66:48-64

Tanabe S, Iwata H, Tatsukawa R (1994) Global contamination by persistent organochlorines and their ecotoxicological impact on marine mammals. Sci Total Environ 154(2-3):163-177

USEPA (1992) Guidelines for exposure assessment, US Environmental Protection Agency, federal register. 57(104): 22888-22938. http://cfpub.epa.gov/ncea/cfm/recordisplay

USEPA (2000) Guidance for assessing chemical contaminant data for use in fish advisories, volume 2: risk assessment and fish consumption limites. 3rd ed. Washington, DC. http://www.epa. gov/waterscience/fish/guidance.html

USEPA (2012) Edition of the drinking water standards and health advisories, US Environmental Protection Agency, office of water, Washington, DC. http://water.epa.gov/action/advisories/ drinking/upload/dwstandards2012.pdf

Vallero D (2004) Environmental contaminants: assessment and control. Elsevier Academic Press, p 832

Vander Oost R, Beyer J, Vermeulen NPE (2003) Fish bioaccumulation and biomarkers in environmental risk assessment: a review. Environ Toxicol Pharmacol 13:57-149

WHO (1989) Heavy metals-environmental aspects. Environment Health Criteria. No. 85. Geneva

WHO (2011) Guidelines for drinking water quality, 4th edn. World Health Organization Geneva. http://whqlibdoc.who.int/ publications/2011/9789241548151_eng.pdf

Yim UH, Hong SH, Shim WJ, Oh JR (2005) Levels of persistent organochlorine contaminants in fish from Korea and their potential health risk. Arch Environ Contam Toxicol 48(3):358-366

Zeng J, Yang LY, Chuai XM, Chen XF, Zhao HY, Wu QL (2013) Comparison of metal(loid) concentrations in water, sediments and fish from two large shallow lakes. Int J Environ Sci Technol 10:1209-1218

Zhang Z, Hong H, Zhou J, Wang XJ (2002) Transport and fate of organochlorine pesticides in the River Wuchuan. J Environ Monit 4:435-441

Zrncic S, Oraic D, Caleta M, Mihaljevic Z, Zanella D, Bilandzic N (2013) Biomonitoring of heavy metals in fish from the Danube River. Environ Monit Assess 185:1189-1198 